E3S Web of Conferences 1, 08002 (2013)

DOI: $10.1051 / \mathrm{e} 3$ sconf/20130108002

(c) Owned by the authors, published by EDP Sciences, 2013

\title{
Comparison of Levels and Sources of Lead in Modern and Ancient Soils in Low Volga Steppes
}

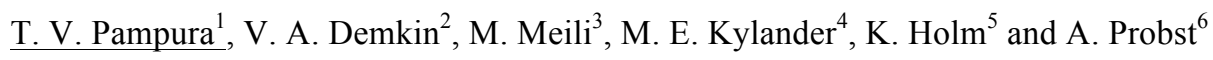

${ }^{1}$ Laboratory of Physical Chemistry of Soils, Institute of Physicochemical and Biological Problems in Soil Science RAS, Pushchino, RUSSIA, pampura@rambler.ru

${ }^{2}$ Laboratory of Archaeological Soil Science, Institute of Physicochemical and Biological Problems in Soil Science RAS, Pushchino, RUSSIA, demkin@issp.serpukhov.su

${ }^{3}$ Department of Applied Environmental Science (ITM), Stockholm University, Stockholm, SWEDEN, markus.meili@itm.su.se

${ }^{4}$ Department of Geological Sciences, Stockholm University, Stockholm, SWEDEN, malin.kylander@geo.su.se

${ }^{5}$ Department of Applied Environmental Science (ITM), Stockholm University, Stockholm, SWEDEN, karin.holm@itm.su.se

${ }^{6}$ Laboratoire Ecologie Fonctionnelle et Environnement CNRS/UPS/INPT ENSAT, Toulouse, FRANCE, anne.probst@ensat.fr

\begin{abstract}
Concentrations and isotopic compositions of lead in the total and mobile (acid-soluble and carbonate- bound) forms were determined in remote and roadside Chestnut soils in the dry steppe region of Low Volga, Russia. As a reference to evaluate the level of modern soil contamination with lead, we used ancient soil buried under a Bronze Age kurgan about 4500 years ago. In comparison with buried soil, the roadside modern soils showed clear signs of anthropogenic influence such as elevated total and mobile $\mathrm{Pb}$ concentrations and fractions of the mobile forms in the total pool of $\mathrm{Pb}$, higher ratios of $\mathrm{Pb} / \mathrm{Ti}$ and $\mathrm{Pb} / \mathrm{Sc}$, and a shift of $\mathrm{Pb}$ isotopic compositions towards the less radiogenic signatures found in modern Russian aerosols and gasoline. In the remote modern soils, however, these signs of anthropogenic influence were much less pronounced and could be observed only in the mobile fractions of $\mathrm{Pb}$, but were practically undetectable in terms of concentrations and isotopic compositions of total lead.
\end{abstract}

Key words: Heavy metals, $\mathrm{Pb}$ isotopes, speciation of $\mathrm{Pb}$, historically buried soils, pre-industrial pollution, environmental reconstruction, soil contamination.

\section{Introduction}

The history of anthropogenic $\mathrm{Pb}$ deposition in Europe over millennia has been recorded in peat and ice archives showing that the first signs of air pollution with anthropogenic lead dated back to $3500-4000$ years BP. A clear peak has been detected during the Greek-Roman period around $0 \mathrm{AD}$, and another pollution increase occurred after 1000 AD matching metallurgy development in Europe. Industrial revolution and especially lead production and use of leaded gasoline after World War II resulted in further increase of atmospheric lead pollution (Bindler et al., 2008, Weiss et al., 1999). However, the actual effect of anthropogenic lead input via atmosphere on soils remains unclear for lack of an "uncontaminated" reference baseline. We propose to use as a basis for comparisons the paleosols preserved under archeologically dated burial mounds (kurgans) and thus protected from air pollution during a known period. Combining analyses of $\mathrm{Pb}$ isotope profiles in paleosols and in their modern analogues may provide a novel opportunity to compare sources and levels of metal in soils at present and in ancient times. Ancient soil buried below an archeologically dated kurgan (burial mound of a nomadic tribe) in the Low Volga region of Russia was investigated and compared to modern roadside and "remote" soils in order to evaluate the anthropogenic $\mathrm{Pb}$ impact.

\section{Materials and Methods}

The studied site was located in the dry steppe zone of Low Volga, near the village Perekopka, Volgograd region, Russia, in the area of Chestnut soils. A burial mound with a height of $2 \mathrm{~m}$ was dated back to the Bronze Age, Catacomb culture, about 4500 years BP. 
A modern reference (remote) soil was selected within 30 $\mathrm{m}$ from the kurgan. In order to study the isotopic composition of modern gasoline-derived $\mathrm{Pb}$, samples of surface soil $(0-5 \mathrm{~cm})$ were collected along a motorway (Moscow-Volgograd M6, 49 $00^{\prime} \mathrm{N}, 4^{\circ} 11^{\prime}$ E) at distances of 2, 5 and $10 \mathrm{~m}$ from the road.

The lead concentration and isotopic composition in the total $\mathrm{Pb}$ and two mobile forms (acid-soluble, extracted by $0.5 \mathrm{~N} \mathrm{HNO}_{3}$, and carbonate-bound, extracted by ammonium acetate buffer with $\mathrm{pH} 4.8$ ) were analyzed in each horizon of the modern and buried soil profiles using Q-ICP-MS. Further, ${ }^{210} \mathrm{~Pb}$ was determined using gamma-spectrometry in the Observatoire Midi Pyrénées-LEGOS-LAFARA, France.

\section{Results and Discussion}

The protection of soil buried by a kurgan from contamination with modern lead by deposition and downward migration was investigated using airborne unsupported ${ }^{210} \mathrm{~Pb}$ as a natural analog. The activity of unsupported ${ }^{210} \mathrm{~Pb}$ was found significantly different from 0 only in the surface $(0-10 \mathrm{~cm})$ horizon of modern soil, whereas the activity in the top $(0-10 \mathrm{~cm})$ layer of buried soils (about $2 \mathrm{~m}$ below the modern surface of the kurgan) did not exceed the analytical uncertainty. This suggests that kurgans indeed protect buried soil from modern airborne $\mathrm{Pb}$ deposited during the past 2 centuries at least.

Concentrations of total and mobile $\mathrm{Pb}$ (acid-soluble and carbonate-bound), the fraction of mobile $\mathrm{Pb}$ in the total pool, and the enrichment of $\mathrm{Pb}$ relative to $\mathrm{Ti}$ and $\mathrm{Sc}$ were much higher in the roadside soils than in all others. In the roadside soils, the isotopic composition of $\mathrm{Pb}$ in both mobile and total forms was enriched by less radiogenic $\mathrm{Pb}$ as found in Russian gasoline and modern aerosols according to Mukai et al. (2001) (Fig. 1).

Modern soils remote from roads differed from the buried soil much less than roadside soils. However, concentrations and fractions of mobile $\mathrm{Pb}$ were significantly higher in this modern soil than in paleosol. This may be treated as evidence of an anthropogenic lead input, on the other hand, this may as well be caused/explained by natural processes (such as a higher degree of biological activity and weathering), as indicated by a higher $\mathrm{Ba} / \mathrm{Sr}$ ratio (weathering index), content of organic matter and Mn-hydroxide in the modern soil. The isotopic composition of carbonate-bound lead in the modern soil was slightly shifted towards $\mathrm{Pb}$ in gasoline and modern aerosols (Fig. 1). However, signs of possible anthropogenic influence (less radiogenic $\mathrm{Pb}$ composition in combination with increased concentration) as noted in the mobile fraction of $\mathrm{Pb}$ from modern remote soils are practically invisible in the levels and isotopic ratios of total $\mathrm{Pb}$.

\section{Conclusions}

The results of our study do not confirm the common concept of a global character and high level of modern soil contamination by $\mathrm{Pb}$. Rather, the $\mathrm{Pb}$ contamination of soils in the study area seems limited and localized along motorways.
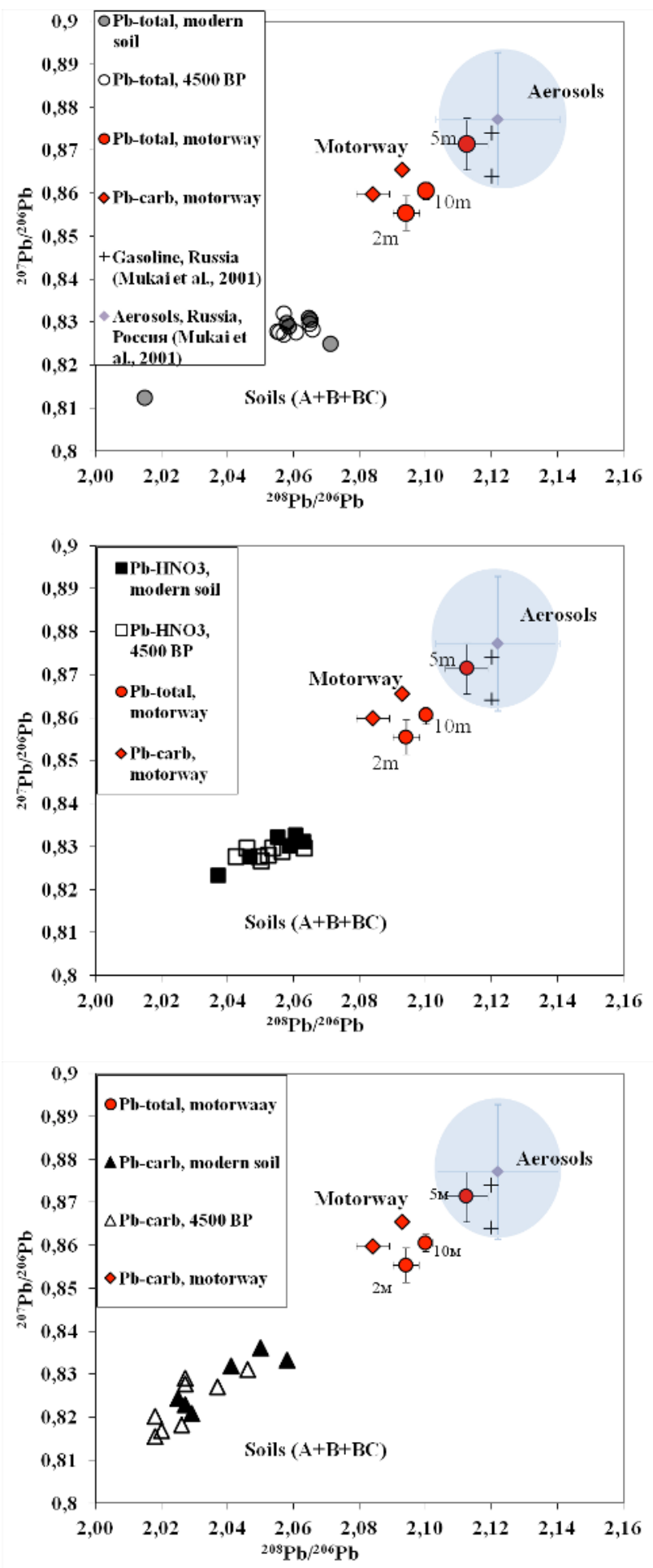

Fig. 1 Isotopic composition of total, acid-soluble and carbonate-bound forms of $\mathrm{Pb}$ in buried soils, modern remote soils (A, B, and $\mathrm{BC}$ horizons) and roadside soils (A1 horizon, 2, 5, $10 \mathrm{~m}$ from a motorway). Isotopic compositions of total $\mathrm{Pb}$ in Russian gasoline and aerosols are taken from Mukai et al. (2001). The shadowed areas correspond to the mean value \pm standard deviation for Russian aerosols. 


\section{Acknowledgements}

We thank the Russian Foundation for Basic Research and CNRS, France (projects 09-04-00233, 09-05-91058 -нцни -a, PICS $\mathrm{N}^{\circ} 4982$ ) and the Presidium of the Russian Academy of Sciences (the Program for Basic Research, directions 4 and 25) for their financial support.

\section{References}

Bindler R, Renberg I, Klaminder J. Bridging the gap between ancient metal pollution and contemporary biogeochemistry. J Paleolimnol 2008; 40:755-770. Mukai H, Machida T, Tanaka A, Yelpatievskiy P.V, Uematsu M. Lead isotope ratios in the urban air of eastern and central Russia. Atmos Environ 2001; 35: 2783-2793.

Weiss D, Shotyk W, Kempf O. Archives of atmospheric lead pollution. Naturwissenschsften 1999; 86: 262-275. 